\title{
О ПОЈМУ НАСЛЕЪЕНИ ЈЕЗИК КРОЗ ПРИЗМУ БИЛИНГВИЗМА
}

\begin{abstract}
У раду се у основним цртама представља појам наслеђеног језика (енг. heritage language), како би се приближио истраживачима који се баве овим питањем, јер је релативно нови предмет проучавања заступљен у литератури. Полази се од тога да је овај термин поникао у теорији билингвизма, па је у раду дефинисан и сам билингвизам, као и критеријуми за разграничавање матерњег и страног језика. Приказане су теорије усвајања које теже да издвоје усвајање наслеђеног језика као засебну категорију у односу на усвајање језика у монолингвалној ситуацији, као и у односу на усвајање страног језика. Теорија незавршеног усвајања подразумева да наслеђени говорници не усвајају комплетно циљни језик као што то чине монолингвали, док теорија успореног усвајања упућује на то да наслеђени говорници имају засебан систем усвајања циљног језика у односу на монолингвале. Закључује се да су наслеђени говорници посебна група која има карактеристике и монолингвала и говорника страног језика, али не припада ниједној комплетно, већ представља једну хетерогену групу.
\end{abstract}

Кључне речи: наслеђени језик, билингвизам, теорије усвајања

\section{1. Увод}

Рад настоји да расветли термин наслеђеног језика, који је релативно нов предмет проучавања у страној литератури, а који је проистекао из области билингвизма. Циљ рада је да у основним цртама прикаже сам појам наслеђеног језика, односно да да̂ преглед литературе која се бави његовим дефинисањем. Сматрамо да ће разјашњење овог термина бити потпуније само ако се претходно дефинише билингвизам и матерњи језик, што овај прегледни рад чини потпунијим од других који су се бавили сличном тематиком, а који су се углавном изоловано дотицали појма наслеђеног језика, без прегледа критеријума за дефинисање билингвизма (нпр. KELLEHER 2010; POLINSKY, SCONTRAS 2019 итд.).

\footnotetext{
${ }^{1}$ anakrsticka94@gmail.com

${ }^{2}$ Овај рад финансирало је Министарство просвете, науке и технолошког развоја Републике Србије према Уговору број 451-03-1766/2020-14/1, који је склопљен са Филозофским факултетом у Новом Саду.
} 
Након краћег уводног дела, следи друго поглавље, у коме је дефинисан билингвизам, и које је подељено на два потпоглавља. У првом потпоглављу разграничавају се матерњи и нематерњи језик, наводе се и образлажу фактори у постављању таквих граница, а у другом потпоглављу се излажу различити случајеви који улазе у категорију билингвизма (билингвалне индивидуе или групе). У првом потпоглављу трећег поглавља представљен је преглед терминологије у вези са наслеђеним језиком и њему сличним појмовима, а затим су у другом потпоглављу приказане и теорије усвајања по којима се у новије време усвајање и учење наслеђеног језика издваја као посебна област у односу на традиционално усвајање и учење страног језика. У закључку су та поглавља укратко резимирана.

\section{2. Билингвизам - дефинисања}

Билингвизам, односно двојезичност се дефинише као „способност за говорење два језика" (KRISTAL 1985). Двојезичност је у домену социолингвистике сложено питање, јер подразумева разне факторе за врсте и нивое „двојезичних ситуација” (KRISTAL 1985), а такође је и теоријска основа за примењену лингвистику, која се бави наставом и усвајањем страног језика. Осим социолингвистике и примењене лингвистике, билингвизам је често предмет проучавања и у другим гранама лингвистике, нарочито у психолингвистици и неуролингвистици, које испитују репрезентацију језика у мозгу билингвала, затим језичку производњу, разумевање, али и језичке поремећаје (као што је нпр. афазија) на примерима билингвала. Очигледно je да појам билингвизма прелази оквире лингвистичких дисциплина, те је предмет интересовања и педагогије, а још уже, дидактике и методике учења страног, односно нематерњег језика.

У вези са дефинисањем билингвизма у научној и стручној светској литератури одувек је било спорова и полемике, с обзиром на велики број критеријума за поделу. У том светлу важно је поменути часопис Bilingualism: Language and Cognition, који се штампа од 1998. године, у издању Cambridge University Press-a. Наиме, он се бави управо мултидисциплинарном природом билингвизма, посматра га из језичке, психолингвистичке и неуролошке перспективе. Нека од конкретних подручја проучавања које издвајамо из радова у овом часопису јесу језичка компетенција билингвала, учење језика код деце и одраслих и сл.

\subsection{1. Матерњи језик}

Да би се разумела двојезичност, мора се претходно утврдити шта се све подразумева под појмом матерњи језик, а шта у том случају спада у нематерњи. Неопходно је затим тумачити када је особа билингвална, јер детаљније дефинисање матерњег језика проблематизује бинарни однос матерњи : страни језик. 
Матерњи језик се може дефинисати на основу буквалног тумачења термина, односно као језик мајке/оца, дакле, родитеља. У литератури се може наћи дефиниција по којој је то први језик (L1), којем је особа изложена од рођења, нарочито у „критичном периоду”з (BLOOMFIELD 1994). Међутим, синонимност термина матерњи и први језик се релативизује у случајевима деце из билингвалне породице (да ли су то уједно два матерња, тj. два L1 и по којим критеријумима?), или у случајевима када је први језик исто што и доминантни, а то више не мора нужно бити матерњи (ако матерњи и даље дефинишемо као језик из детињства, језик родитеља). Уједно, термин матерњи језик је често негативно маркиран, јер се употребљава да означи језик етничке мањине (нпр. настава на матерњем/домаћем језику) (SKUTNAB-KANGAS 1981: 21).

Насупрот претходном, лингвисти релативизују сам термин идеални говорник матерњег језика (ideal native speaker), који се користио у примењеној лингвистици при проучавању усвајања другог језика управо јер се чини утопијским (SANIEI 2011). Неки од предлога за прецизирање таквог појма су „интеркултурални говорник” (енг. intercultural speaker) (JAEGER 2001) или пак „идеални корисник језика” (енг. ideal language user) (SANIEI 2011).

Како општа дефиниција матерњег језика и термин идеалног говорника не покривају све услове и могуће језичке ситуације, потребно је извести одређене критеријуме, за које такође не можемо са сигурношћу тврдити да су основани према свим условима, јер њихов број није лако установити. Ипак, они би могли бити окосница за представљање јасније слике о матерњем језику и његовом разграничавању од страног језика.

У раду се служимо критеријумима Тове Скутнаб Кангас (1981), која издваја критеријум порекла, компетенције (владања језиком, степена усвојености), функције (примене), ставова (унутрашње и спољашње идентификације). Сваки од наведених критеријума ауторка проблематизује. Тако је први - порекло, који се заснива на идеји да је матерњи језик којим мајка говори, тј. који је дете прво научило, усложњен ситуацијом са билингвалним породицама, у којој би дете онда имало два матерња језика ${ }^{4}$. Ауторка опажа да је таква двојезичност ретка у случају да се дете рађа у окружењу као што је један језик код куће, други ван ње.

Под другим критеријумом подразумева се компетенција. Кангас (1981: 23) у овкиру овог критеријума наводи да се матерњи језик дефинише као језик „који неко лице најбоље зна”, и издваја четири стандардна подручја

\footnotetext{
${ }^{3}$ Под критичним периодом у лингвистици подразумева се кључно време најранијих година људског живота за усвајање првог језика. Уколико недостају улазне језичке информације (language input) током овог периода, особа неће постићи потпуно усвајање тог језика.

4 у поглављу о билингвизму релативизоваћемо ту констатацију када будемо изнели критеријуме за дефинисање типова билингвизма, мада је та тема уско повезана са темом о матерњем језику, односно са тиме шта подразумевамо под матерњим језиком.
} 
језичке компетенције: разумевање, говорење, читање и писање, којима она придодаје и мишљење (1981: 39). Ситуација је и у овој подели нешто сложенија ако уведемо појам билингвизма, те се поставља питање постоје ли људи који обама језицима једнако добро располажу и на основу чега се то оцењује. С друге стране, ауторка је свесна да је много чешћи пример у ком билингвални говорник обично један језик говори исто као монолингвал, а други нешто слабије зна (1981: 40).

Трећи критеријум - критеријум функције дефинише матерњи језик као језик који се највише користи. Но, уколико се узме у обзир ситуација када је особа „приморана” на тај језик (нпр. у професионалној употреби), може се рећи да јесте највише коришћен, али никако нужно и матерњи, јер се особа можда тек подстакнута послом сусреће са тим језиком (према SKUTNABKANGAS 1981: 24). Стога ауторка прави разлику између дефиниције по функцији и функционалне диференцијације (диглосије), у чијем случају би прва морала да подразумева једно право билингвално друштво да би се могло говорити о постојању два матерња језика (1981: 41-42).

Четврти критеријум - ставови - односи се на дефинисање матерњег језика као језика којим се лице идентификује. „Унутрашња идентификација” (SKUTNAB-KANGAS: 25) подразумева личну идентификацију особе са језиком који представља културну традицију групе којој особа припада, док „спољашња идентификација” (SKUTNAB-KANGAS 1981: 26) означава да одређена група, тј, друштво прихвата индивидуу као изворног говорника. Овај критеријум је релативизован питањима као што су: да ли је неопходно да неко савршено говори један језик да би био прихваћен као изворни, или још тежим питањем: по чему неко процењује да је изворни говорник неког језика? (SKUTNAB-KANGAS 1981: 43-44).

\subsection{2. Билингвизам - критеријуми, типови, монолингвизам : билингвизам}

С обзиром на то да је и сам термин матерњи језик тешко дефинисати, како у погледу тога ко је идеални матерњи говорник тако и због недоумице која настаје у билингвалној ситуацији билингвизам, уколико се узму у обзир разни типови и критеријуми, настали на основу различитих говорних ситуација. Ако пођемо од питања може ли особа бити потпуно билингвална, морамо у обзир узети валидне критеријуме за дефинисање особе као монолингвалне, односно шта особу чини матерњим говорником. Ако би особа испуњавала све те критеријуме у оба језика, била би „потпуни билингвал” (SKUTNAB-KANGAS 1981: 46-47). У супротном, када у оба то не задовољава, била би „обострани полулингвал”, а уколико не задовољава у једном, онда бисмо је назвали „скоро билингва-

\footnotetext{
${ }^{5}$ Може ли особа имати два матерња језика?
} 
лом" (SKUTNAB-KANGAS 1981: 46-47). Подела је применљива и на ситуацију усвајања другог језика (SLA - second language acquisition), односно када се други језик усваја из околине, или се учи са циљем, с тим што процес усвајања другог језика свакако није исти као процес усвајања матерњег. Наиме, разлике постоје и на нивоу усвајања матерњег код монолингвала и код усвајања два матерња код билингвала, као и на нивоу усвајања два матерња језика и учења новог језика. Ситуација постаје компликованија уколико се случају придода и усвајање наслеђеног језика, што бисмо могли да дефинишемо тек ако имамо нешто јаснију представу о типовима билингвизма и начину на који се језик у тим разним условима усваја и учи.

Двојезичност се може дихотомно делити: „природна двојезичност” насупрот „школској” (SKUTNAB-KANGAS 1981: 115-117). Према ауторки, природни билингвал је онај који је рано научио оба језика без формалног образовања, супротно школској билингвалности. Сходно томе, лингвисти су у прошлости различито гледали на то шта је прави билингвизам: за неке је искључиво природни билингвизам био прави, а у случају школског је чак сматрано да та особа и уз све напоре учења неће достићи билингвизам (MALBERG 1977). Данас, један од можда главних критеријума при одређивању билингвизма, поготову у области социолингвистике и језичке политике, свакако јесте питање ита сматрамо једним језиком (питање територијално-дијалекатске раслојености и сл.).

Друга класификација може бити на сложену, координирану и субординирану двојезичност (WEINREICH 1967). Према Вајнрајх, сложени билингвали имају један семантички систем који примењују у оба језика, те нису увек свесни који језик користе (то су најчешће билингвали из билингвалне породице). Аутор координиране билингвале дефинише као особе које имају посебне семантичке системе, јер су их усвојили у у другачијим условима (на пример елитни и народни билингвали). Субординирани билингвали семантички систем првог усвојеног језика преводе на касније усвојени језик, те је он подређен (често су то елитни и народни билингвали, односно примери школског билингвизма).

Осим што постоји више начина да се разложе билингвалне ситуације и да се сходно њима билингвизам дефинише, остаје отворено питање како се билингвизам разликује од монолингвизма у погледу проиеса и исхода усвајања језика и језичке компетенције. Оно око чега се (неуро)лингвисти, али и неуропсихолози најмање споре јесте да мозак монолингвала и билингвала другачије функционише на плану језика, те се за билингвале користи термин multi-competent language users (COOK 1995). Имајући у виду да се термин односи на знање два или више језика, Кук $(1995,1999)$ предлаже да оно што усваја неко из другог језика није исто као оно што се усваја из првог. Односно, Кук истиче да систем страног језика L2 говорника није исти као систем тог језика код матерњег говорника. Затим, аутор сматра да L2 говор- 
ници имају друге циљеве у учењу језика од монолингвала, користе више језичких функција, које монолингвалима често нису ни потребне, а притом су L2 говорници под утицајем знања других језика које познају. Кук наглашава да знање матерњег језика код L2 говорника није исто као знање матерњег код монолингвала, што би значило да тај други или трећи (или било који следећи) може да утиче на све аспекте језика уопште код индивидуе. Најзад, аутор заузима став да учење другог језика свакако побољшава метајезичку свест и когнитивне способности. Бијалисток (2001) опажа да деца која су учила други језик боље перцепирају језик и боље разграничавају значење и форму. Кук (1995), дакле, сматра кориснике другог језика за потпуно други тип усвајача језика од монолингвала, те их зато не треба ни сматрати неуспешним говорницима матерњег језика.

Закључцима наведених аутора додали бисмо и сопствено запажање да je у данашњици тешко наћи правог/чистог монолингвала, водећи се чињеницом да монолингвизам подразумева познавање искључиво једног језика и непознавање ниједне речи на другом језику. Међутим, остаје отворено сложено питање на основу чега би требало особу сматрати монолингвалом, односно билингвалом, јер се језичке компетенције разликују на индивидуалном плану.

\section{3. Наслеђени језик (енг. heritage language)}

\section{1. Поглед на доступне термине}

Термин говорник наслеђеног језика (енг. heritage speaker) први пут је употребљен у Канади средином седамдесетих година прошлог века (CUMMINS 2005), али је у жижи интересовања у Сједињеним Америчким Државама од деведесетих година 20. века. У најширем смислу, термин наслеђени говорници се односи на децу или одрасле чланове лингвистичке мањине која је одрастала уз један језик код куће и уз језик већине (MONTRUL 2010: 4). Наслеђени језик би у том смислу био било који језик осим доминантног/доминантних у одређеном друштвеном контексту, као што је енглески доминантни у Сједињеним Америчким Државама, а сви други би могли да буду наслеђени (KELLEHER 2010). Међу лингвистима је заједно са термином настала и полемика у вези са тим шта све сматрати наслеђеним језиком и ко све спада у наслеђене говорнике. Полински и Каган (2007) сматрају да ранг наслеђених говорника може драстично да варира по флуентности, од готово перфектне до изузетно слабе. Према појединим лингвистима, термин се може односити на језик породице или заједнице којој индивидуа припада, а да језик уопште не познаје (VALDES 2005; KELLEHER 2010).

У Сједињеним Америчким Државама се често на наслеђене језике реферише као на стране језике (енг. foreign languages), али они свакако нису 
страни тим одређеним особама или заједницама већ су, напротив, познати, јер многи могу на тим језицима говорити и споразумевати се, те би требало да термин наслеђени језик обухвати све те односе између недоминантног језика и особе, односно заједнице (парафразирано према KELLEHER 2010). Келехер (2010) сматра да термин језик мањине (енг. minority language), такође коришћен у истом значењу као термин наслеђени језик, ствара два проблема: један је негативна социјална конотација коју носи са собом, а други се огледа у чињеници да тај језик заправо може бити језик неке етничке већине, мимо постојећег доминантног. Алтернативни термини варирају у употреби, попут језика заједнице (енг. community language), или кућног језика (енг. home language) (према KELLEHER 2010). Оба термина указују на окружење индивидуе, које је главни извор употребе тог језика.

Џошуа Фишман (2001) издваја три типа наслеђених језика ${ }^{6}$ у Сjeдињеним Америчким Државама, који највише наглашавају социјални и историјски аспект односа тих језика са енглеским: језик имиграната (енг. immigrant language), језик домородацуа (енг. indigenous language), колонијални језик (енг. colonial language). Аутор наводи да се први односи на онај тип језика који говоре имигранти који су дошли у Сједињене Америчке Државе након што је држава постала независна. Језик имиграната може да се поклапа са колонијалним - језиком неке европске групе која је колонијализовала Сједињене Америчке Државе и тим се језиком и даље тамо говори: холандски, немачки, фински, француски, шпански... Пример поклапања је шпански, који је био колонијални, а сада је значајан језик имиграната (према FISHMAN 2001). Језик домородаца представља онај тип језика којим су говорили, или и даље говоре амерички староседеоци (према FISHMAN 2001). Многи језици су изумрли или се таквима сматрају, а многима изумирање свакодневно прети, јер је број говорника све мањи.

Термин treasure language - језик који треба заштити, предложили су Рама људи из Никарагве, уместо термина наслеђени језик и језик домородаuุa, које сматрају погрдним. Термин одражава потребу говорника да очувају свој матерњи језик што дуже (парафразирано према GRINEVALD, PIVOT 2013).

Као корелативни термин горенаведеним стоји доминантни језик (енг. dominant language), односно у друштвеном контексту језик већине, а у лингвистичком, језик који код наслеђеног говорника преовладава у одређеном периоду живота, јер је њему далеко више и дуже изложен него свом првобитно L1 језику (уколико се наслеђеним језиком сматра и онај језик који се само осећа својим, а не и говори, онда је код таквих особа доминантни одувек и био L1). За доминантне језике везана је појава лингвистичког/језичког империјализма, која подразумева трансфер доминантног језика на друге

\footnotetext{
${ }^{6}$ Треба напоменути да је мишљење међу лингвистима подељено око тога шта се од ова три сматра као наслеђени, а шта као сродни, али независни тип језика.
} 
људе, а односи се на исказивање надмоћи, у прошлости милитаристичке и колонијалне, данас више економске.

Када се пак говори о терминологији која се користи за именовање особа које припадају оваквој специфичној билингвалној ситуацији, лингвисти су на разне начине покушавали да их сврстају у неки од билингвалних оквира. Већ поментутом Куковом ставу $(1995,1999)$ о билингвалима као мултикомпетентним корисницима придодајемо и његов термин L2 корисник (енг. L2 user), који се односи на говорника наслеђеног језика. Валдес (2005) дели мишљење са Куком у погледу тога да је термин SLA (second language acquisition) незадовољавајућ за различите случајеве говорника из језичке мањине, али уместо термина $L 2$ корисник, употребљава $L 1 / L 2$ корисник. По њеном мишљењу (2005: 414), тај термин би требало да се односи на билингвалне индивидуе које манифестују различите способности у своја два језика и који спадају у континуум разних типова билингвала, које приказује на следећи начин:

Табела бр. 1 (преузета од VALDES 2005)

Monolingual

Monolingual

A A $\mathrm{A}$ Ab Ab Ab Ab AB aB aB Ba Ba Ba Ba Ba B

Тако би, на пример, говорник који је скоро имигрирао у Сједињене Америчке Државе био Ab (доминантан је имигрантски језик), а већ четврта генерација би била Ва (којој је енглески доминантан, L1 језик, а ипак има одређено знање на имигрантском језику) (према VALDES 2005: 414).

\section{2. Теорије усвајања}

Јасно је да већ са самом употребом другачијих и нових термина лингвисти покушавају да укажу на различитост наслеђених језика и њихових говорника у односу на друге врсте билингвизма, па чак и на разлике међу индивидуалним или групним примерима говорника наслеђених језика. Међутим, да би се доказале разлике, истраживачи морају да прате процес усвајања и учења тог језика код појединаца или групе од детињства до одраслог доба, тачније под којим условима и како се то усвајање и учење јављају, а када изостају (парафразирано према MONTRUL 2010).

Од посебног значаја за разумевање језичког феномена који показују наслеђени говорници јесу такозване теорије усвајања (енг. acquisition theories), које теже да објасне зашто се способности говорника наслеђених језика разликују од њихових монолингвалних вршњака (PIRES, ROTHMAN 2009). Силвина Монтрул $(2002,2008,2010)$ нарочито се бавила тим специфичним усвајањем језика код наслеђених говорника. Наиме, подсећајући на 
критични период усвајања основног структурног система језика (прве три до четири године живота) и на развијање метајезичке свести од раног школског периода, тврди да у теорији деца из билингвалне и мултилингвалне породице могу да усвоје језичке способности као монолингвали, при чему наведено зависи од великог броја фактора. Ауторка (2010: 10) сматра да су углавном наслеђени језици језици мањине, који се највише говоре само код куће, и то у неформалном контексту. Ауторка наводи и да говорници наслеђеног језика усвајају тај језик натуралистички, као и монолингвали, али постоје различити случајеви: симултани билингвали, који су изложени и наслеђеном језику и језику већине од рођења, јер један или оба родитеља знају и језик већине, или је дете одгајано на том језику; секвенцијални билингвали, којима је наслеђени био доминантан до пете године. Још неки од типова наслеђених говорника су они који су у периоду од седме до девете године имигрирали са својим родитељима, те су језик већине усвајајали у школи, а наслеђени је им је већ био конституисан. У таквим случајевима обично млађа браћа или сестре имају слабије способности на наслеђеном језику од старијих, а често се дешава да браћа и сестре између себе и са другом „наслеђеном” децом говоре искључиво на језику већине (MONTRUL 2010: 10). Уколико се уведе термин незавршеног усвајања (енг. incomplete acquisition) (према MONTRUL 2002, 2008; POLINSKY 2008), које се јавља код говорника наслеђених језика којима након критичног периода L2 постаје доминантан језик, а остају често неписмени или недовољно елоквентни на наслеђеном језику, можемо се тврдити да је незавршено усвајање јаче код симултаних него код секвенцијалних билингвала, јер су ови други наслеђеном језику били дуже и јаче изложени (према MONTRUL 2002, 2008; POLINSKY 2008). Термин близак незавршеном усвајању је губљење (енг. attrition), које Монтрул (2002) дефинише као губитак одређених својина језика након што су биле усвојене на нивоу матерњег говорника. Губитак се јавља када L2 постане доминантан (као код говорника наслеђеног језика), или у обрнутом смеру: када се говорник врати у средину где је први језик доминантан, онда ће уследити губитак L2.

Монтрул (2010: 11) сматра да усвајање наслеђеног језика има сличне одлике као рано усвајање L1, али не у свим секвенцама, јер усвајање наслеђеног јесте незавршено L1 усвајање, и то не у монолингвалној, већ билингвалној средини. У том смислу, усвајање наслеђеног језика је, према ауторки, сличније усвајању L2 код одраслих, које се дефинише као неуспешно, неконвергентно. L2 говорници праве трансфер из свог првог језика и не савладају их заувек чак ни после инструкција, док L1 говорници савладавају грешке природно, без потребе за инструкцијама и никад их више не праве. Мада појединци сматрају да је могуће да се L2 усаврши као L1, ауторка сматра да то није загарантовано и да се фосилизащија језика ${ }^{7}$ може

\footnotetext{
${ }^{7}$ Процес у ком неисправан језик остаје навика и не може се више променити.
} 
десити у сваком тренутку (MONTRUL 2010: 11).

Усвајање наслеђеног језика може се пратити у пресеку између усвајања L1 и L2. (MONTRUL 2010: 12):

,1) L1 и HL (heritage language): рана изложеност језику; усмене улазне информације које се усвајају натуралистички; контрола над деловима језика усвојеним врло рано (фонологија, одређен лексички фонд, одређене лингвистичке структуре.

2) L2 и HL: грешке током развоја и трансфера; резултат је варијабилна језичка способност (обично је незавршена); честа је фосилизација; мотивација и афинитети играју велику улогу у развоју језичке способности”.

Према Монтрул (2010: 12) усвајање L1 разликује се од усвајања L2 и HL по томе што усвајање L1 подразумева да је резултат успешан и комплетан, фосилизације нема, мотивација и афинитети не играју никакву улогу, усвајају се комплексније структуре и вокабулар већ после пете године, када се развијају металингвистичке способности. С друге стране, оно што усвајање L2 разликује од усвајања L1 и HL јесте каснија изложеност језику, варирање улазних језичких информација у школском или природном окружењу (писано и усмено), могућа незавршеност граматике (немогућност да се развију друге структуре и вокабулар), искуство са писменошћу и формалним инструкцијама (парафразирано према MONTRUL 2010: 12).

У новије време јављају се опречна размишљања поводом првобитних поставки Монтрул о незавршеном усвајању. Наиме, Пасквал и Ротман (2012) сматрају да се то не може звати незавршеним усвајањем, јер је сама ситуација говорника наслеђеног језика и говорника матерњег језика неупоредива. Они наводе да су улазне језичке информације другачије код првих и зависе од различитих фактора, нпр. губитака у преносу с генерације на генерацију и сл. Патнам и Санчез (2013) пак померају фокус са резултата усвојеног наслеђеног језика на процес усвајања, као и са зависности од улазних језичких информација на фреквентност процесирања за разумевање и коришћење тог језика. Такође, Монтрул је замерено што њена теорија о незавршеном усвајању занемарује неке друге значајне појаве (delayed acquisition, input variation, cross-linguistic influence). Успорено усвајање (delayed acquisition) подразумева диференцијацију између матерњих говорника и говорника наслеђеног језика, јер су оба типа прошли кроз исте фазе у усвајању, али је то дуже трајало код говорника наслеђеног језика, због мање количине улазних информација, или њихове другачије природе. Та другачија природа улазних информација се односи на термин варијащија инпута (input variation), који означава да су оне могле долазити из разних варијетета језика, било стандардног или дијалекатског, те је то свакако утицало на 
резултат наслеђеног језика код појединца или групе. И последњи термин cross-linguistic influence (међујезички утицај) тиче се самог трансфера неких језичких одлика (енг. language transfer) и правила из доминантног језика у наслеђени.

O односу L1 и L2 говорника уопште доста се говорило и из угла генеративиста, који сматрају да та два типа имају веома другачије механизме учења, према хипотези фундаменталне разлике (енг. FDH - fundamental difference hypothesis) (BLEY-VROMAN 1989, 2009). Према Блеј Вроману и другим генеративистима који су део Универзалне граматике (УГ) (CHOMSKY 1986) L1 усвајање језика код детета је вођено урођеним механизмима. Они сматрају да дете има приступ УГ само за време критичног периода и да зато људи који су изашли из пубертетног периода, а уче други језик неће моћи да користе те исте лингвистичке механизме као L1 говорници. Као такви, L2 говорници могу да се ослањају једино на своја знања и принципе из првог језика, и притом морају да користе разне способности за решавање проблема, као што су аналогија и шаблонизирање. Што се говорника наслеђених језика тиче, Монтрул (2010) истиче да су они су пример прекинутог L1 усвајања, док је говорник још имао приступ универзалној граматици, па се код говорника наслеђених језика могу наћи неке језичке способности које су у том истом периоду усвојили и L1 говорници (binding constraints, wh-movement, аспекти лексичке семантике), али имају проблема са оним аспектима за које је било потребно бити изложен њима у школском периоду (специфични вокабулар, категорија субјунктива и сл.).

Приликом поређења HL и L2 говорника и њихових способности, када су подучаване особе из обе категорије, Монтрул (2010: 16) истиче да је у пракси је утврђено да показују различита језичка знања. На пример, ауторка сматра да су говорници наслеђених језика далеко напреднији у изговору од L2 говорника. Међутим, Монтрул (2010: 16) такође истиче да се ово не може рећи за морфосинтаксу (нпр. конгруирање), јер је мање пресудна у критичном периоду од фонологије, те се очекује да и HL и L2 говорници показују трансфер из својих доминантних језика. Наиме, иста ауторка (2010: 17) наводи да се говорници наслеђених језика боље показују у усменој језичкој продукцији, као и у слушању и разумевању, јер су они превасходно природни и често неписмени говорници тог језика, а да с друге стране, с обзиром на то да L2 говорници други језик усвајају најчешће писмено и кроз инструкције, исти надмашују HL говорнике када се захтева металингвистичко и експлицитно знање језика.

\section{4. Закључак}

У раду је у основним цртама представљен појам наслеђеног језика, 
са претходним освртом на билингвизам и разграничавање појмова који се јављају у оквиру билингвизма. Тако је истакнут проблем дефинисања матерњег језика и наведени су критеријуми за његово прецизирање, при чему је као чест проблем препознато поистовећивање са термином први језик.

Издвојени су и различити критеријуми за одређивање типова билингвала - расветљавање овог проблема је значајно како би се идентификовало ком типу билингвала припадају наслеђени говорници. Међутим, како је сама група билингвала изузетно хетерогена, исто се односи и на наслеђене говорнике, па је дефинисање самим тим отежано.

У поглављу о наслеђеном језику препознати су термини који су се досад јављали у сродном контексту са термином наслеђеног језика, а нарочито се образлаже теорија усвајања наслеђеног језика, при чему се истичу појмови незавршеног усвајања, губљења и фосилизације језика. Самим тим, термин наслеђени језик разликује се од усвајања матерњег језика у монолингвалној ситуацији, који одликује завршено и успешно усвајање, као и од усвајања страног језика јер је он најчешће пример секвенцијалног билингвизма, насупрот наслеђеном, који је пример симултаног. Другачија мишљења се такође могу наћи у литератури, према којима се не говори о незавршеном усвајању код наслеђеног језика, већ о својеврсном успореном усвајању, другачијем од оног код монолингвала. У односу на говорнике страног језика истиче се да наслеђени имају другачије компетенције, јер су језик усвајали натуралистички, те су вештији у усменој комуникацији, али слабији у продуковању неких експлицитних граматичких особина језика, за разлику од говорника истог као страног језика.

Анализирана литература показује да постоји свест о томе да наслеђене говорнике треба посматрати као посебну групу билингвала која има карактеристике и монолингвала и говорника страног језика, али не припада ниједној комплетно, и да уједно представља једну хетерогену групу, што чини дефинисање термина наслеђени језик комплексним питањем.

\section{Цитирана литература}

BIALYSTOK, Ellen. Bilingualism in development. Cambridge University Press, 2001. BLEY-VROMAN, Robert. "The evolving context of the fundamental difference hypothesis". Studies in Second Language Acquisition, 31, 2009: 175-198.

BLEY-VROMAN, Robert. The logical problem of second language acquisition. Cambridge University Press, 1989: 41-68.

BLOOMFIELD, Leonard. Language. Motilal Banarsidass Publ., 1994.

CHOMSKY, Noam. Knowledge of language. New York: Praeger, 1986.

COOK, Vivian. "Going beyond the native speaker in language teaching". TESOL Quarterly, 33(2), 1999: 185-209. 
COOK, Vivian. "Multi-competence and the learning of many languages". Language, Culture and Curriculum, 8(2), 1995: 93-98.

CUMMINS, Jim. "A proposal for action: Strategies for recognizing language competence as a learning resource within the mainstream classroom". Modern Language Journal, 89, 2005: 585-591.

FISHMAN, Joshua. "300-plus years of heritage language education in the United States”. In J. K. Peyton, D. A. Ranard, \& S. McGinnis (Eds.), Heritage languages in America: Preserving a national resource, Washington, DC \& McHenry, IL: Center for Applied Linguistics \& Delta Systems, 2001.

GRINEVALD, Colette. Bénédicte Pivot. „On the revitalization of a 'treasure language’: The Rama Language Project of Nicaragua". In Jones, Mari; Ogilvie, Sarah (Eds.), Keeping Languages Alive: Documentation, Pedagogy and Revitalization. Cambridge University Press, 2013.

JAEGER, Kirsten. "The intercultural speaker and present-day requirements regarding linguistic and cultural competence". Sprogforum, 19, 2001: 52-56.

KELLEHER, Ann. "What is a heritage language?" CAL: Center for Applied Linguistics. Center for Applied Linguistics, 2010.

KRISTAL, Dejvid. Enciklopedijski rečnik moderne lingvistike. Beograd: Nolit, 1985.

MALBERG, Bertil. Is there semi-lingualism? Sydsvenska Dagbladet, 1997.

MONTRUL, Silvina. "Current Issues in Heritage Language Acquisition". Annual Review of Applied Linguistics, 30, 2010: 3-23.

MONTRUL, Silvina. Incomplete acquisition in bilingualism. Re-examining the age factor.

Amsterdam: John Benjamins, 2008.

MONTRUL, Silvina. "Incomplete acquisition and attrition of Spanish tense/aspect distinctions in adult bilinguals". Bilingualism: Language and Cognition, 7, 2002: $1-18$.

PASCUAL, Diego. Jason Rothman. "The (il)logical problem of heritage speaker bilingualism and incomplete acquisition". Applied Linguistics, 33 (4), 2012: 450-455.

PIRES, Acrisio. Jason Rothman. "Disentangling sources of incomplete acquisition: An explanation for competence divergence across heritage grammars". International Journal of Bilingualism, 13 (2), 2009: 211-238.

POLINSKY, Maria. “Gender under incomplete acquisition: Heritage speakers' knowledge of noun categorization”. Heritage Language Journal, 6 (1), 2008: 40-71.

POLINSKY, Maria. Olga Kagan. "Heritage languages: In the 'wild' and in the classroom". Language and Linguistics Compass, 1 (5), 2007: 368-395.

POLINSKY, Maria. Gregory Scontras. "Understanding heritage languages". Bilingualism: Language and Cognition, 23 (1), 2019: 1-41.

PUTNAM, Michael. Liliana Sanchez. "What's so incomplete about incomplete acquisition? A prolegomenon to modeling heritage language grammars". Linguistic Approaches to Bilingualism, 3 (4), 2013: 478-508. 
SANIEI, Andisheh. Who is an ideal native speaker? International Conference on Languages, Literature and Linguistics, Singapore: IACSIT Press, 2011.

SKUTNAB-KANGAS, Tove. BILINGVIZAMDA ili NE. Beograd: Zavod za udžbenike i nastavna sredstva, 1981.

WEINREICH, Uriel. Languages in Contact. Findings and Problems. Mouton \& Co, The Hague, 5th printing, 1967.

VALDES, Guadalupe. "Bilingualism, heritage language learners, and SLA research: Opportunities lost or seized?". The Modern Language Journal, 89 (3), 2005: 410-426.

VALDES, Guadalupe. "The teaching of heritage languages: an introduction for Slavicteaching

Professionals". The learning and teaching of Slavic languages and cultures, Olga Kagan and Benjamin Rifkin (eds.), 2000: 375-403.

Ana M. Krstić

\section{ABOUT THE CONCEPT OF HERITAGE LANGUAGE THROUGH THE OUTLINES OF BILINGUALISM}

The paper outlines the concept of heritage language in order to give a more detailed explanation, because it is a relatively new subject of study represented in the literature. The paper defines bilingualism itself, including certain criteria for defining bilingualism and mother tongue. Acquisition theories are presented that put acquisition of heritage language as a separate category in relation to the language acquisition of a monolingual, as well as in relation to the acquisition of a foreign language. Incomplete acquisition theory implies that heritage speakers do not fully adopt the target language as monolinguals do, while delayed acquisition theory suggests that heritage speakers have a separate target language acquisition system over monolinguals. It is concluded that heritage speakers are a special group that has the characteristics of both monolinguals and foreign language speakers, but does not belong to any of them completely, and at the same time represents one heterogeneous group.

Keywords: heritage language, bilingualism, acquisition theories 